Keywords:

Tension Wood

Opposite Wood

Cellulose Pulp

Historic:

Received 13/12/2016

Accepted 24/07/2017

Palavras chave:

Madeira tracionada

Madeira oposta

Polpa celulósica

+Correspondence: walterboschetti@gmail.com

DOI:
Walter Torezani Neto Boschetti ${ }^{1+}$, Juarez Benigno Paes², Graziela Baptista Vidaurre ${ }^{2}$, Marina Donária Chaves Arantes ${ }^{3}$, João Gabriel Missia da Silva²

\section{QUALITY OF REACTION WOOD IN Eucalyptus TREES TILTED BY WIND FOR PULP PRODUCTION}

ABSTRACT: This study aims to evaluate the quality of normal, tension and opposite wood of eucalyptus trees lengthwise, in straight and inclined stems, affected by wind action. It also aims to explain the pulping parameters resultant from the quality of the wood. The trees were grouped into four tilt ranges, ranging from 0 to $50^{\circ}$, and the basic density, chemical composition of the wood, and performance in kraft pulping were assessed. Normal and tension wood had similar basic densities; while for opposite wood, the density was lower, being responsible for a decrease in reaction wood density. The chemical composition of the wood was influenced by the presence of reaction wood in the stem. Tension and opposite wood showed lower levels of extractives and lignin and higher holocellulose content when compared to normal wood, with favorable wood quality for pulping. The increase in holocellulose content and the reduction of lignin and extractives content contributed positively to a more delignified pulp and reduction of the Kappa number. However, after cooking the reaction wood under the same conditions as those of normal wood, reaction wood pulping tends to have a lower screen yields. Due to differences in basic density and chemical constituents between opposite and normal wood, it is recommended not to designate the opposite wood as normal wood.

\section{QUALIDADE DA MADEIRA DE REAÇÃO EM ÁRVORES DE EUCALIPTO INCLINADAS POR VENTOS PARA PRODUÇÃO DE POLPA}

RESUMO: Este estudo objetivou-se avaliar a qualidade da madeira normal, tracionada e oposta no sentido longitudinal de árvores de eucalipto com o fuste reto e inclinado, atingidas por ação de ventos, e explicar os parâmetros da polpação em decorrência da qualidade do lenho. As árvores foram agrupadas em quatro faixas de inclinação variando de $0^{\circ}$ a $50^{\circ}$, e avaliado a densidade básica, composição química da madeira, e o desempenho na polpação Kraft. A madeira normal e a tracionada tiveram densidades básicas semelhantes, já a densidade da madeira oposta foi inferior, sendo responsável pela diminuição da densidade básica da madeira de reação. A constituição química da madeira foi influenciada pela presença da madeira de reação no tronco, tendo a madeira tracionada e oposta menores teores de extrativos e ligninas, e maior teor de holocelulose, em relação à madeira normal, sendo favoráveis na qualidade da madeira para a polpação. $O$ aumento do teor de holocelulose e a redução dos teores extrativos e ligninas contribuíram positivamente para obter uma polpa mais deslignificada, e reduzindo o numero kappa. Todavia, quando realizados cozimento na madeira de reação com as mesmas condições da madeira normal, a polpa de reação tende a ter menor rendimento depurado. Em decorrência das diferenças de densidade básica e dos constituintes químicos entre madeira oposta e normal, recomenda-se a não designar a madeira oposta como madeira normal.

' Federal University of Viçosa - Viçosa, Minas Gerais, Brazil

${ }^{2}$ Federal University of Espirito Santo- Jeronimo Monteiro, Espírito Santo, Brazil

${ }^{3}$ Federal University of São João Del-Rei -Sete Lagoas, Minas Gerais, Brazil 


\section{INTRODUCTION}

Wood from fast-growing forest species, such as eucalyptus clonal hybrids for the pulp industry, is the main driver for the improved performance of the forestry plantation sector in Brazil.

However, young trees with very tall stems have high slenderness indexes and are more vulnerable to wind action, which is a natural and uncontrollable factor. Such occurrences in commercial plantations can create stress on the trees, and in more dramatic scenarios, strong winds can cause damage, such as the tilting of the stem at different angles in trees of a single plantation and in trees with ages below the rotation cycle for cutting.

Reaction wood is induced in inclined stems in an effort to return the tree to its vertical axis through symmetry biomechanics. In broadleaf trees, reaction wood is called tension wood, and it occurs in the upper part of the inclined stem (DONALDSON; SINGH, 2016). Once tension wood forms in the stem, the anatomical structure and the chemical and physical characteristics of the wood are also modified, due to the presence of the gelatinous layer (CLAIR; THIBAULT, 200I; WASHUSEN; EVANS, 200I; WASHUSEN; ILIC, 200I; SOUSA, 2004). As for the reaction wood formed on the opposite side to the tilting, it carried little importance, due to the result of the suppressed growth on this side of the stem. However, some authors have mentioned an excessive porosity in this type of wood (AGUAYO et al. 20I0; BOSCHETTI et al., 20I5a).

The quality of the reaction wood is the key element to achieve pulp with high yields and high bleachability (COLODETTE, 20I4). The divergence of the reaction wood properties compared to normal wood in eucalyptus forest plantations influences its quality, and depending on the intensity of the affected population, the manufacturing process in the pulping industry must be modified for better results.

Unusual tension wood characteristics may significantly impact bleached pulp production, but little is currently known about it as it relates to eucalypt trees grown in tropical regions. A study carried out with Eucalyptus globulus wood showed that kraft pulps derived from reaction wood present lower yields and a higher kappa number in relation to opposite wood, for a given effective alkali charge (AGUAYO et al., 20I2). The high cellulose content in Populus tristis tension wood was proven desirable for pulp yield and pulp brightness. However, the presence of the gelatinous layer hinders fiber collapse and lowers fiber strength, giving rise to bulky and porous paper sheets (ISEBRANDS; PARHAM, 1974; PARHAM et al., 1977).

Verifying the pulping parameters is essential to ascertain the quality of the wood from forest plantations. Determining the density and chemical characterization of wood is essential to explain the behavior of the wood before pulping parameters, especially when it comes to little studied matters, as is the case of reaction wood on the tension and opposite side.

This study aims to evaluate the quality of normal, tension and opposite wood of eucalyptus trees lengthwise, in straight and inclined stems, affected by the action of winds, as well as to explain the pulping parameters due to the quality of the wood.

\section{MATERIAL AND METHODS}

\section{Sampling characterization}

The wood used was from commercial forest plantations of Eucalyptus grandis $x$ Eucalyptus urophylla clones from Ipaba municipality, located in the region of the Vale do Rio Doce, east of Minas Gerais. The region is located in between $19^{\circ} 23^{\prime} 45^{\prime \prime}$ South Latitude and 42²3'40" West Longitude.

The trees were planted in February 2007 on flat ground with a spacing of $3.00 \times 3.33 \mathrm{~m}$. The area was struck by heavy winds in November 2009, 33 months after planting, reaching speeds of up to $72 \mathrm{~km} \cdot \mathrm{h}^{-1}$. The cutting procedure took place in January 2013, 38 months after the occurrence of the winds in the plot, and $7 \mathrm{I}$ months after the date of planting. Twenty (20) trees were randomly selected and separated into groups according to the tilt angle.

From Group I, we obtained normal wood from trees possessing a straight stem, i.e. zero tilting. In Groups 2, 3 and 4, the trees were classified into $15^{\circ}$ intervals (Figure I). The division of trees per tilt group allowed a better assessment of the characteristics of the wood in the trees inclined with different bottomup lengths and mainly in the area in which a consolidated arrow by wind actions was formed. The tilt angle of the trees was determined according to (BOSCHETTI et al. 20l5b).

Five trees were collected for each tilt category. Each tree was divided into positions 0, 25, 50, 75, 100\% of the commercial length of the trunk. In each position, 3.0 $\mathrm{cm}$ thick discs were removed, one for density analysis and another for determining chemical composition. 
Samples were taken from "Side A" and "Side B" of the normal wood of discs from non-tilted trees. Wedges were removed from the discs of trees with an inclined stem to sample the sides above and below the incline, respectively, tension and opposite wood. In positions $12.5,37.5,62.5$ and $87.5 \%$ we collected $75 \mathrm{~cm}$ long logs, which were later debarked and processed into chips to conduct the Kraft pulping (Figure 2).
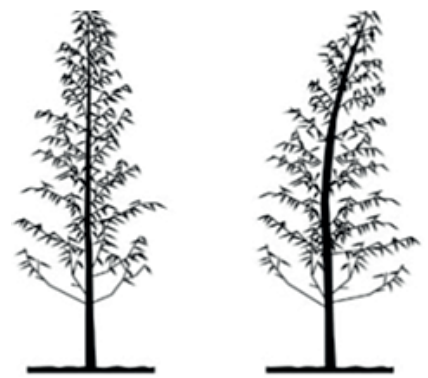

$$
\text { Control Group - } \theta_{\mathrm{F} 1}^{\circ}=0^{\circ}
$$
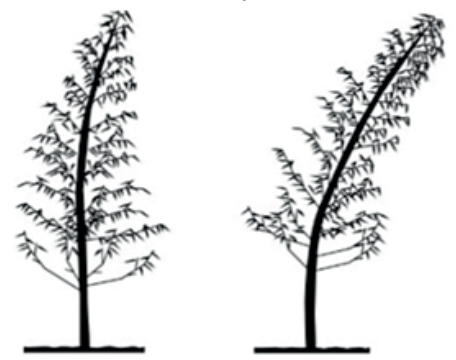

Group 2(F2) $-5^{\circ}<\theta^{\circ} \mathrm{F} 2 \leq 20^{\circ}$

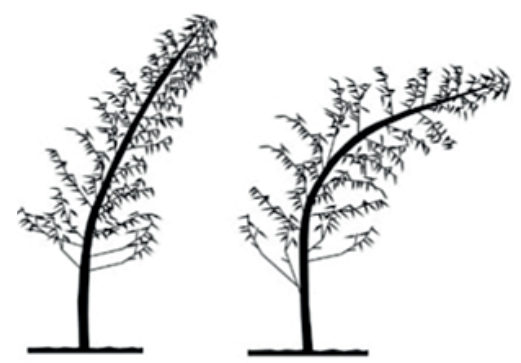

Group $3(\mathrm{~F} 3)-20^{\circ}<\theta^{\circ} 3 \leq 35^{\circ}$

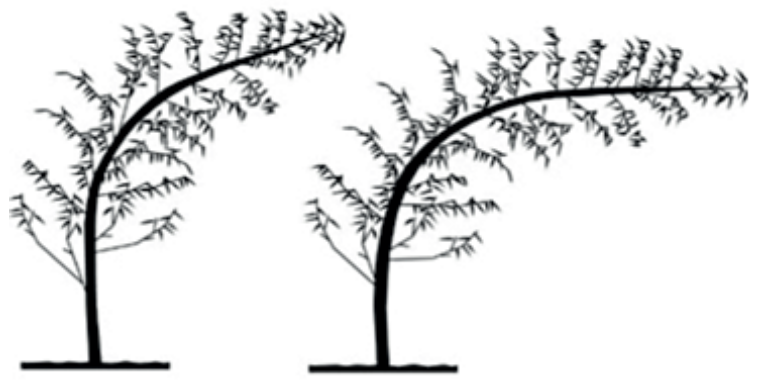

Group 4 (F4) $-35^{\circ}<\theta_{\mathrm{F} 4}^{\circ} \leq 50^{\circ}$

FIGURE I Tilting range groups and tilting angles.

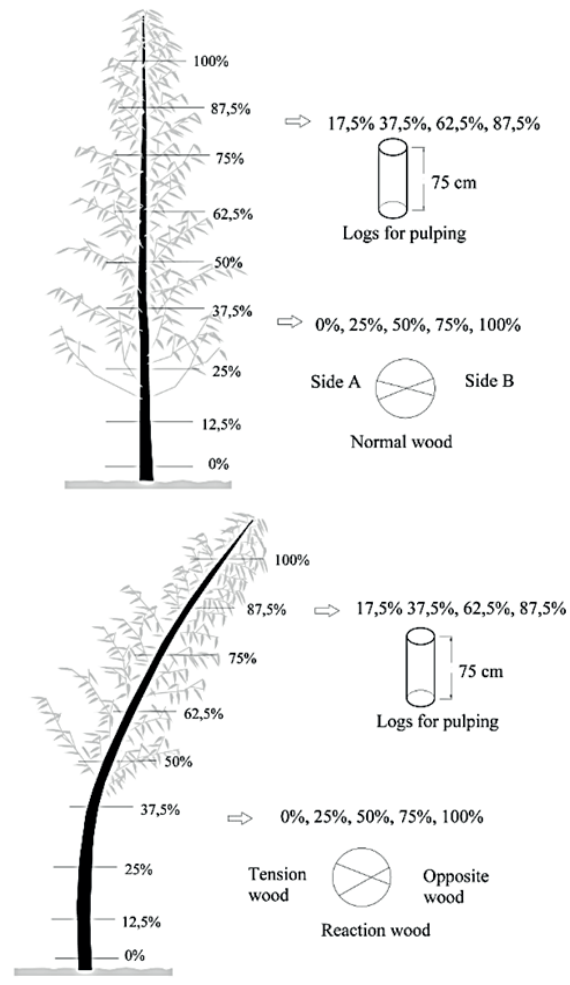

FIGURE 2 Sampling for quality check of wood and pulping.

\section{Determining basic density, chemical characterization and kraft pulping of the wood}

Basic density was obtained according to the Regulatory Brazilian Norm (Norma Brasileira Regulamentadora) - NBR 1194, from the Brazilian Association of Technical Standards (Associação Brasileira de NormasTécnicas) - ABNT (2003).

The contents of extractives in wood were determined according to the Technical Association of the Pulp and Paper Industry -TAPPI 264 om-82 (1992). The insoluble lignin was determined by the Klason method, modified according to the procedure proposed by Gomide and Demuner (1986). As for the soluble lignin, it was determined through spectrophotometry, according to Goldschimid (197I), considering the total lignin content as the sum of the soluble and insoluble lignin values. The holocellulose content was determined as the difference between the total dry weight and total lignin content plus extractives.

The Kraft cooking of wood chips was performed in a laboratory digester. 200 grams of wood chips were subjected to a fixed concentration of $15 \%$ active alkali and $25 \%$ sulfidity. The heating time in the reactor was 90 minutes until it reached $170^{\circ} \mathrm{C}$ and another 60 minutes of cooking at $170{ }^{\circ} \mathrm{C}$. The times and temperatures for each cooking ramp were controlled electronically via the 
machine panel. From the cooking, we could determine the screen yields and the Kappa number of the resultant pulp.

\section{Statistical analysis}

The data was analyzed in a completely randomized design. For pulping, we considered the treatments arranged in split plots. For basic density and chemical characterization, we considered the treatments in subsplit plots. Plots (tilt range), subplots (stem position), and sub-sub plot (coordinated disk).

The data of the plots and sub sub-plots were statistically evaluated through an analysis of variance and, as a result of the $\mathrm{F}$ Test, the averages for the treatment of plots and sub-sub plots were compared through Tukey's Test, tested at a 5\% probability. As for the subplots (stem position), they were statistically analyzed through regression analysis.

\section{RESULTS AND DISCUSSION}

\section{Basic density and chemical characterization of the wood}

The average values of wood density to the tilting ranges are shown in Table I, which indicates the behavior of the density of normal and reaction (tension and opposite) wood according to the variation of the severity of inclination of the stems.

Average values of basic density between normal and reaction wood differed statistically according to Tukey's Test. For reaction wood, there was also a statistical difference between tension and opposite wood. There was no statistical model to explain the behavior of the density in the longitudinal direction of the stem in all tilting ranges for normal and reaction (tension and opposite) wood.

TABLE I Average values of basic density of opposite and tension wood in different tilt ranges in six-year-old Eucalyptus grandis $x$ Eucalyptus urophylla clone trees.

\begin{tabular}{cccc}
\hline \multirow{2}{*}{ Tilting ranges } & \multicolumn{3}{c}{ Basic density of the wood $\left(\mathrm{g}^{\circ} \mathrm{cm}^{-3}\right)$} \\
\cline { 2 - 4 } & Side $\mathrm{A}$ & Side B & Average \\
\hline \multirow{2}{*}{ Normal wood $\left(0^{\circ}\right)$} & $0.483 \mathrm{Aa} *$ & $0.480 \mathrm{Aa}$ & $0,48 \mathrm{I} \mathrm{A}$ \\
& $6.9 \% * *$ & $6.8 \%$ & $6.7 \%$ \\
\hline & Tension wood & Opposite wood \\
\hline \multirow{2}{*}{ Reaction wood $\left(5^{\circ}-20^{\circ}\right)$} & $0.492 \mathrm{Aa}$ & $0.438 \mathrm{Bb}$ & $0.465 \mathrm{AB}$ \\
& $7.7 \%$ & $6.1 \%$ & $9.1 \%$ \\
Reaction wood $\left(21^{\circ}-35^{\circ}\right)$ & $0.481 \mathrm{Aa}$ & $0.425 \mathrm{Bb}$ & $0.453 \mathrm{AB}$ \\
& $9.5 \%$ & $8.4 \%$ & $10.9 \%$ \\
Reaction wood $\left(36^{\circ}-50^{\circ}\right)$ & $0.467 \mathrm{Aa}$ & $0.421 \mathrm{Bb}$ & $0.434 \mathrm{~B}$ \\
& $10.9 \%$ & $7.3 \%$ & $10.7 \%$ \\
\hline \multirow{2}{*}{ Average } & $0.481 \mathrm{a}$ & $0,441 \mathrm{~b}$ & \\
\hline
\end{tabular}

*Averages followed by the same letters, uppercase letters vertically and/or lowercase letters horizontally, do not differ statistically according to Tukey's Test $(p \geq 0,05)$. **Dispersion of values in comparison with the average.
It is possible to observe that there was a trend toward a decrease in the basic density in wood as the slope of the eucalyptus trees increased.

In normal wood (from non-inclined trees) there were higher values of basic density; reaction wood from trees that were tilted by the wind displayed lower values.

We can also notice the dispersion of values around the average was higher on the sloping trees, indicating greater variability of basic density in the stems with the presence of reaction, tension and opposite wood, respectively.

In tension wood, the average values of basic density were similar to those of normal wood of trees with a straight stem. As for the opposite wood, values were approximately I I\% lower than normal and tension wood. Thus, opposite wood induced a decrease in the basic density of the inclined trees.

Greater density values in tension wood in comparison with opposite wood were found by Jourez et al. (200I) in Populus euramericana, Ruelle et al., (2007) in three different species, and various studies with eucalyptus wood show that the density of tension wood is higher than that of opposite wood, but not necessarily higher than that of normal wood. In the study conducted by Chauhan and Walker (20II) E. regnas was found to have $40 \%$ higher density in tension wood when compared to opposite wood.

In the cellulose industry, due to the standardization of pulp cooking parameters, it is ideal to have the same cooking method, chips with a more homogeneous basic density and chemical composition of the wood. Furthermore, the wood density difference can be related to the anatomical characteristics of the wood, especially fiber dimensions. Thus, smaller values of basic density in opposite wood can be explained by the significant increase in the frequency of vessels, which consequently decreases the percentage of fibers, as observed by Boschetti et al. (2015a).

The increased frequency of vessels in opposite wood is also characteristic of $E$. globulus (AGUAYO et al. 2010). Nevertheless, the fiber structure significantly influences the behavior of the pulp for papermaking production (GOMIDE et al. 2005; JOSELEAU et al. 20I2), in which case, in addition to the fiber quality indices for the production of cellulose such as the Runkel Ratio, wall fraction and flexibility of fibers, other characteristics must be considered when it comes to reaction wood, such as the presence of gelatinous layer on the tension fibers and its intensity (FOSTON et al. 20I I).

Dadswell and Wardrop (1949) had already mentioned that the basic density of the wood is greater for tension than normal wood, following a ratio of $4: 3$. 
In this study, we found the same proportion cited by the authors, but between tension and opposite wood.

It is important to note the difference between normal and opposite wood. In this study, normal wood was considered the one produced by trees without the presence of tension wood, being based on non-inclined trees.

The density of normal and tension wood had virtually no relation to one another in this study; however, we should pay attention to the lower density found in inclined trees, and we should be careful when using the basic density of a tree as a wood quality parameter for pulp production, due to the variability of the density found within a leaning tree, and hence the generation of wood chips with greater variability in density. Similarly, Washusen and Ilic, (200 I) also stressed the weak relation between basic density and tension wood in ten-yearold E. globulus. The authors had already warned about the use of this material for pulp production due to the variability of its properties.

\section{Chemical characterization of the wood}

Table 2 shows the percentage of the chemical composition of normal and reaction (tension and opposite) wood in relation to the variation of the degree of inclination of eucalyptus trunks. Statistical differences were observed according to Tukey's Test, in the contents of holocellulose, lignin and extractives, between normal and reaction wood. For reaction wood, there was also a statistical difference between tension and opposite wood.

It was not possible to formulate a model to explain the behavior of the density or of the chemical constituents of the wood in the longitudinal direction of the stem at all tilting ranges for normal and reaction (tension and opposite) wood.

TABLE 2 Average values of the levels of extractives, lignins and holocellulose in normal, tension, and opposite wood in different tilt ranges in six-year-old Eucalyptus grandis $\mathrm{x}$ Eucalyptus urophylla clones tilted by winds.

\begin{tabular}{|c|c|c|c|c|c|c|c|}
\hline \multirow{2}{*}{ Variable } & \multirow[b]{2}{*}{ Side } & \multicolumn{6}{|c|}{ Tilting ranges } \\
\hline & & $\left(0^{\circ}\right)$ & & $\left(5^{\circ}-20^{\circ}\right)$ & $\left(21^{\circ}-35^{\circ}\right)$ & $\left(36^{\circ}-50^{\circ}\right)$ & Average \\
\hline Extractive & A & $3.5 \mathrm{aA} *$ & TW & $2.4 \mathrm{bB}$ & $1.9 \mathrm{cB}$ & $2.4 \mathrm{bB}$ & $2.7 \mathrm{~B}$ \\
\hline content & B & $3.8 \mathrm{aA}$ & OW & $2.9 \mathrm{bA}$ & $2.6 \mathrm{cA}$ & $3.0 \mathrm{bA}$ & $3.0 \mathrm{~A}$ \\
\hline (\%) & Average & $3.7 \mathrm{a}$ & - & $2.7 \mathrm{~b}$ & $2.3 \mathrm{c}$ & $2.7 \mathrm{~b}$ & - \\
\hline Lignin & A & $30.5 \mathrm{aA}$ & TW & $27.5 \mathrm{bB}$ & $27.2 \mathrm{bB}$ & $27.6 \mathrm{bA}$ & $28.2 \mathrm{~B}$ \\
\hline content & B & $30.2 \mathrm{aA}$ & OW & $28.9 \mathrm{bA}$ & $28.2 \mathrm{bA}$ & $27.4 \mathrm{cA}$ & $28.7 \mathrm{~A}$ \\
\hline$(\%)$ & Average & $30.4 \mathrm{a}$ & - & $28.2 \mathrm{~b}$ & $27.7 \mathrm{~b}$ & $27.4 \mathrm{~b}$ & - \\
\hline Holocellulose & A & $65.7 \mathrm{bA}$ & TW & $70.0 \mathrm{aA}$ & $70.7 \mathrm{aA}$ & $70.0 \mathrm{aA}$ & $69.1 \mathrm{~A}$ \\
\hline content & B & 66. I cA & OW & $68.0 \mathrm{bB}$ & $69.2 \mathrm{abB}$ & $69.6 \mathrm{aA}$ & $68.2 \mathrm{~B}$ \\
\hline$(\%)$ & Average & $65.9 \mathrm{~b}$ & - & $69.0 \mathrm{a}$ & $70.0 \mathrm{a}$ & $69.8 \mathrm{a}$ & - \\
\hline
\end{tabular}

TW, OW = Tension and Opposite wood, respectively.

*Averages followed by the same letters, uppercase letters vertically and/or lowercase letters horizontally, do not differ statistically according to Tukey's Test $(p \geq 0,05)$.
The variation of the angle of inclination of trees influenced the chemical composition of the wood, with a clear distinction between normal and reaction wood. However, in sloping trees, the difference in the levels of chemical constituents was little affected by the severity of the inclination.

Reaction wood displayed a greater level of holocellulose content when compared to normal wood (approximately $3.6 \%$ more). This is a result favorable for the Kraft pulp industry, because a higher yield is possible to be achieved, as well as greater productivity while consuming less liquor in the cooking and bleaching processes of the pulp (COLODETTE; GOMES, 20I5).

Tension wood has a greater amount of cellulose due to the chemical structure of gelatinous layer inside the fibers (BOWLING; VAUGHN, 2008; 2009). Nonetheless, this study also found that opposite wood has a higher percentage of holocellulose when compared to normal wood, (approximately $4.5 \%$ more).

Comparing reaction wood within the respective tilt ranges, tension wood displayed greater holocellulose content than opposite wood. On average, tension wood was $2 \%$ more than opposite wood and $6.5 \%$ more than normal wood. This result is in agreement with Guimarães (2007) who observed similar results in reaction wood with $E$. grandis.

Quantifications of the extractives and lignin contents are important in many uses of wood. As a consequence of the higher holocellulose content in reaction wood, extractive and lignin content in reaction wood was lower than in normal wood (approximately $31 \%$ fewer extractives in the reaction wood and $13 \%$ less lignins).

Comparing the reaction wood, tension wood displayed lower content of extractives and lignins than opposite wood, approximately $21 \%$ less extractives than opposite wood and $2.5 \%$ less lignins. Similarly, Aguayo et al., (20I2) also found higher extractive content and lignin in the opposite wood of $E$. globulus compared to tension wood. These differences may be more prominent when comparing tension to normal wood, with a decrease of approximately $40 \%$ and $10 \%$ in extractives and lignin content, respectively. We also found lower content of extractives and lignin in tension wood when compared to E. grandis by Sousa (2004).

The lower extractive and lignin contents in reaction wood are favorable for the production of Kraft cellulose, improving the delignification rate in both cooking and bleaching. Greater lignin and extractive contents mean higher consumption of chemicals in the Kraft process; tending to add the 
solid load in the liquor and increase the capacity of the recovery boiler (COLODETTE; GOMES, 20I5).

\section{Kraft pulping of the wood}

Table 3 shows the values of screen yields of the Kraft pulp and the Kappa number in normal and reaction wood with regard to the longitudinal position of the trunk in different tilting classes. The average values of screen yields and the Kappa number statistically differed, according to Tukey's Test, between normal and reaction wood. Longitudinally, a statistical model to explain the behavior of the pulping parameters remained unattainable.

TABLE 3 Average values of screen yields and of the Kappa number of normal and reaction wood in six-year-old Eucalyptus grandis $\mathrm{x}$ Eucalyptus urophylla clone trees tilted by winds.

\begin{tabular}{|c|c|c|c|c|c|}
\hline \multirow{3}{*}{ Tilting groups } & \multicolumn{5}{|c|}{ Screen yields (\%) } \\
\hline & \multicolumn{5}{|c|}{ Longitudinal position of the stem } \\
\hline & $12.5 \%$ & $37.5 \%$ & $62.5 \%$ & $87.5 \%$ & Average \\
\hline Normal wood $\left(0^{\circ}\right)$ & $53.0 \mathrm{AB}^{*}$ & $53.8 \mathrm{~A}$ & $53.4 \mathrm{~A}$ & $53.0 \mathrm{~A}$ & $53.3 \mathrm{~A}$ \\
\hline Reaction wood $\left(5^{\circ}-20^{\circ}\right)$ & $53.5 \mathrm{~A}$ & $53.7 \mathrm{~A}$ & $52.5 \mathrm{~B}$ & $51.9 \mathrm{~B}$ & $52.9 \mathrm{AB}$ \\
\hline Reaction wood $\left(21^{\circ}-35^{\circ}\right)$ & $53.0 \mathrm{AB}$ & $53.5 \mathrm{AB}$ & $52.4 \mathrm{~B}$ & $51.8 \mathrm{~B}$ & $52.7 \mathrm{~B}$ \\
\hline Reaction wood $\left(36^{\circ}-50^{\circ}\right)$ & $52.5 \mathrm{~B}$ & $53.0 \mathrm{~B}$ & $53.8 \mathrm{~A}$ & $52.6 \mathrm{~A}$ & $52.9 \mathrm{AB}$ \\
\hline \multirow{2}{*}{ Tilting groups } & \multicolumn{5}{|c|}{ Kappa number } \\
\hline & $12.5 \%$ & $37.5 \%$ & $62.5 \%$ & $87.5 \%$ & Average \\
\hline Normal wood $\left(0^{\circ}\right)$ & $16.0 \mathrm{~A}$ & $15.0 \mathrm{~A}$ & $14.7 \mathrm{AB}$ & I5.I A & $15.2 \mathrm{~A}$ \\
\hline Reaction wood $\left(5^{\circ}-20^{\circ}\right)$ & I4.3 BC & I3.2 B & $15.0 \mathrm{~A}$ & $13.8 \mathrm{~B}$ & I4. I B \\
\hline Reaction wood $\left(21^{\circ}-35^{\circ}\right)$ & 13.6 C & I3.4 B & $14.4 \mathrm{AB}$ & $14.3 \mathrm{AB}$ & $13.9 \mathrm{~B}$ \\
\hline Reaction wood $\left(36^{\circ}-50^{\circ}\right)$ & I4.8 B & $12.9 \mathrm{~B}$ & $13.8 \mathrm{~B}$ & $14.3 \mathrm{AB}$ & $13.9 \mathrm{~B}$ \\
\hline
\end{tabular}

Inclination influenced the wood pulping. The reaction wood reached lower Kappa number values, which generated a more delignified pulp due to the reduction in lignin content found in both tension and opposite wood when compared to the normal wood. The higher delignification in the reaction wood may have been due to the lower screen yields in the pulp, because the higher the wood delignification rate in the cooking, the lower the pulp screen yields tend to be.

The decrease in screen yields in the reaction wood may also have been the result of a more porous stem in the opposite wood, which generated wood chips containing a higher frequency of vessels, increasing permeability, in which the fibers may easily have been delignified and possibly degraded until the end of cooking, when compared with wood chips of tension wood. This is assuming that the cooking had the same conditions for all wood chips and that the pulping conditions for normal wood can be aggressive for reaction wood. This explanation is consistent with Guimarães (2007), who noticed that the pulp of opposite Eucalyptus grandis wood had the most degraded carbohydrate chains and lower viscosity when compared to the pulp of reaction wood.

Thus, we emphasize the importance of having the delignification curves for each type of wood in order to know what the most appropriate conditions are , particularly in relation to the active alkali load, for each type of wood.

The variation in yield and Kappa number in stem positions were higher for reaction wood than for normal wood, due to the higher variability of the technological characteristics of wood, density and chemical composition, found in inclined trees. In reaction wood, there was a difference of up $3.7 \%$ between the screen yield averages, compared to $1.5 \%$ in normal wood.

\section{CONCLUSIONS}

Normal and tension wood presented similar basic densities. Meanwhile, the density of the opposite wood was lower, being responsible for the decrease in wood density of trees tilted due to wind action.

The chemical constitution of the wood was influenced by the presence of reaction wood in the stem; tension and opposite wood showed lower levels of lignin and extractives and higher holocellulose content in comparison to normal wood.

The chemical constituents were favorable in the quality of wood for pulping. The increase in holocellulose content and the reduction of lignin and extractive contents contributed positively to a more delignified pulp, reducing the Kappa number. Nevertheless, after cooking reaction wood under the same conditions as those for normal wood, the reaction pulp tends to have lower screen yields.

Due to the differences in basic density and in the chemical constituents between opposite and normal wood, it is not recommended that opposite wood to be designated as normal wood.

\section{REFERENCES}

ASSOCIAÇÃO BRASILEIRA DE NORMAS TÉCNICAS. NBR I 194: Madeira: determinação da densidade básica. Rio de Janeiro, 2003. 6p.

AGUAYO, M. G; QUINTUPILL, L; CASTILLO, R; BAEZA, J; FREER, J; MENDONÇA, R. T. Determination of differences in anatomical and chemical caharacteristics of tension and opposite wood of 8-Year old Eucalyptus Globulus. Maderas. Ciencia y tecnología,v. I2, n. 3, p. 24I-25I, 20 I0.

AGUAYO, M. G.; MENDONÇA, R. T.; MARTÍNEZ, P.; RODRÍGUEZ, J.; PEREIRA, M. Chemical characteristics and Kraft pulping of tension wood from Eucalyptus globulus labill. Revista Árvore, v.36, n.6, p. I I63-I I72. 2012. 
BOSCHETTI, W. T. N; PAES, J. B; OLIVEIRA, J. T. D. S; DUDECKI. L. Características anatômicas para produção de celulose do lenho de reação de árvores inclinadas de eucalipto. Pesquisa Agropecuária Brasileira,v. 50, n. 6, p. 459-467, 20I5a.

BOSCHETTI, W. T. N; PAES, J. B; VIDAURRE, G. B; ARANTES, M. D. C; LEITE, F. P. Dendrometric parameters and eccentricity of the pith in leaning eucalypt trees. Scientia Forestalis, v. 43, n. 108, p. 78I-789. 20I5b.

BOWLING, A. J; VAUGHN, K. C. Immunocytochemical characterization of tension wood: gelatinous fibers contain more than just cellulose. American Journal of Botany, $v$. 95, p. 655-663, 2008.

BOWLING, A. J, VAUGHN, K. C. Gelatinous fibers are widespread in coiling tendrils and twining vines. American Journal of Botany, v. 96, p. 719-727. 2009.

CHAUHAN, S. S; WALKER, J. C. F. Wood quality in artificially inclined I-year-old trees of Eucalyptus regnans - differences in tension wood and opposite wood properties. Canadian journal of forest research,v. 4I, n. 5, p. 930-937, 20II.

CLAIR, B.; THIBAULT, B. Shrinkage of the gelatinous layer of poplar and beech tension wood. IAWA Journal, v.22, n.2, p.|2|-|3|. 200|.

COLODETTE, J. L. Qualidade da Madeira: Elemento chave para a produção de polpa de eucalipto de alto rendimento e branqueabilidade. O Papel, v.75, p.62-63, 2014.

COLODETTE, J. L; GOMES, F. G. B. Branqueamento de polpa celulósica: da produção da plpa marrom ao produto acabado. Federal University of Viçosa, 20I5. 8I6p.

DADSWELL, H. E; WARDROP, A. B. What is reaction wood? Australian Forestry,v. 13, n. I, p. 22-33, 1949.

DONALDSON, L. A; SINGH.A. P. Reaction Wood. In KIM, Y S; FUNADA, R; SINGH, A. P. Secondary Xylem Biology: Origins, Functions, and Applications. 2016, p.93-II0.

FOSTON, M; HUBBELL, C. A. SAMUEL, R; JUNG, S; FAN, H; DING, S.Y; ZENG, Y. Chemical, ultrastructural and supramolecular analysis of tension wood in Populus tremula $\mathrm{X}$ alba as a model substrate for reduced recalcitrance. Energy \& Environmental Science, v.4, n. 12, p. 4962, 201 I.

GOLDSCHIMID, O. Ultraviolet spectra. in SARKANEN, K.V; LUDWIG C.H. Lignins, Wiley Interscience, New York, I97I. p. 24I-246.
GOMIDE, J. L.; DEMUNER, B. J. Determinação do teor de lignina em material lenhoso: método Klason modificado. $\mathbf{O}$ Papel, v.47, n.8, p. 36-38, 1986.

GOMIDE, J. L; COLODETTE, J. L; OLIVEIRA, R. C; SILVA, C. $M$. Technological characterization of the new generation of Eucalyptus clones in Brazil for kraft pulp production. Revista Árvore,v. 29, n. I, p. I29-137, 2005.

GUIMARÃES, C. J. Study of bleaching and physicalmechanical and optical properties from wood pulp traction Eucalyptus grandis. Monography. 93p. 2007, Federal University of Viçosa. Viçosa, Brasil.

ISEBRANDS, J. G.; PARHAM R. A. Tension wood anatomy of short rotation Populus spp. before and after kraft pulping. Wood Science, v.6, p.256-265. 1974.

JOSELEAU, J. P; CHEVALIER-BILLOSTA, V; RUEL, K.. Interaction between microfibrillar cellulose fines and fibers: influence on pulp qualities and paper sheet properties. Cellulose, v. 19, n. 3, p. 769-777, 2012.

JOUREZ, B.; RIBOUX, A.; LECLERCQ, A. Comparison of basic density and longitudinal shrinkage in tension wood and opposite wood in young stems of Populus euramericana cv. Ghoy when subjected to a gravitational stimulus. Canadian Journal of Forest Research, v. 31, n. 10, p. 1676-1683, 200I.

PARHAM; R. A; ROBINSON, K. W; ISEBRANDS J.G. Effects of tension wood on kraft paper from a short rotation hardwood (Populus Tristis $\left.\mathrm{n}^{\circ} \mathrm{I}\right)$. Wood Science and Technology, v.II, p.29I-303. 1977.

RUELLE, J. M; YOSHIDA, B.; CLAIR, B. ; THIBAUT, B. Peculiar tension wood structure in Laetiaprocera (Poepp.)Eichl. (Flacourtiaceae).Trees, v. 2I, p. 345-355, 2007.

SOUSA, L. C. Characterization of tension wood in Eucalyptus grandis and evaluation of its effect on kraft pulp production.2004. 93p. Dissertation.Federal University of Viçosa, Viçosa, Brasil.

TAPPI TECHNICAL DIVISIONS AND COMMITTEES. TAPPI test methods. Atlanta: 1998. 46p.

WASHUSEN, R.; EVANS, R. The association between cellulose crystallite width and tension wood occurrence in Eucalyptus globulus. IAWA Jounal, v.22. p.235-243, 200 I.

WASHUSEN, R; J. ILIC. J. Relationship between transverse shrinkage and tension wood from three provenances of Eucalyptus globulus Labill. Holz als Roh- und Werkstoff. v. 59, n. I, p. 85-93. 200I. 
